\title{
The Role of Perceived Organizational Support to Increase Effect of Organizational Justice Dimension on Organizational Citizenship Behavior
}

\author{
Anak Agung Gde Gria Pemecutan ${ }^{1}$, Ida Bagus Agung Dharmanegara ${ }^{1}$, \\ I Gusti Bagus Udayana ${ }^{1}$

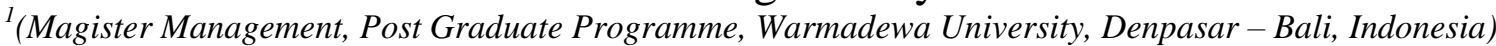

\begin{abstract}
The purpose of this study to examine effect of three organizational justice's component to organizational citizenship behavior directly and indirectly through perceived organizational support. Object of this study are Lecturers in Private Universities in Denpasar Bali. This explanatory study used survey technique with data collected by distributing questionnaires to the all respondents. About 85 Lecturers in Private Universities in Denpasar Bali was taken as sample. PLS (Partial Least Square) method was used to analyze data and find out the relationship and path coefficients among the variables. Regarding all of hypotheses that proposed in this study, there are two hypotheses rejected. Important findings from this study which are: (1) greatest impact with biggest path coefficient are the effect of interactional justice on perceived organizational support; (2) there is important mediating effect of perceived organizational support in justice and extra-role behavior relationship; (3) Key important aspect was interactional justice, which could fostering extra role behavior such organizational citizenship behavior directly, or through perceived organizational support.
\end{abstract}

Keywords: Distributive Justice, Procedural Justice, Interactional Justice, Perceived Organizational Support, Organizational Citizenship Behavior

\section{Introduction}

As a member of the faculty or department at a university, lecturers are professional educators and scientists with the main task of transforming, developing and disseminating science, technology and arts through education, research, and community service. The role of a lecturer in a college is important and strategic, so that is why professionality of lecturers fully required and it is a must. Professional Lecturers will produce qualified students and must have qualified competence and qualifications. From organizational behavior perspective, involvement and participation in the Lecturer development can not be ruled out, especially in private universities. Lecturer as civil servant with role in private universities want to participate on establishing policies and institutional procedures related to work, such as teaching, doing research, or another academic services.

Lecturers need to understand and believe in legitimacy of policies and procedures as if they are ready to be implemented it effectively and willingness to follow the rules. As a human being, lecturers have attitude and behavior which could plays an important role in quality of teaching. Student satisfaction and their perceptions of quality of course are accepted significantly influenced by attitude and behavior of lecturers who taught them. Basically, human resources within an organization must be managed properly so that is expected to boost organizational effectiveness which is visible from division of labor and employment relationship between the work units and sub-systems within it. It is expected to create teamwork between each unit in the organization, which strong teamwork can encourage employees to behave positively towards colleagues is what many previous authors said about organizational citizenship behavior (OCB). Podsakoff et al. [1] mentions several reasons OCB can affect organizational effectiveness, which it could improve co-workers productivity, helping to improve managerial productivity, help to make use of organizational resources for productive purposes efficiently, reduce demands on the provision of resources in general to maintain employees, an effective basis for coordination of activities between team members and working groups.

Grounded in social exchange theory, perceived organizational support is stated contribute to formation of organizational membership behavior of employees or OCB [2]. Previous research has found that employees who feel that they are supported by their organizations tend to respond by engaging in action when forming of organizational citizenship behavior than those who have lower levels of perceived organizational support [3] [4]. According to Greenberg [5], organizational justice refers to employee perceptions of fairness within the organization. Some researchers have reveals that fair treatment is closely linked to employees' behavior and their higher performance [6]. Results of these studies have shown that organizational justice have an effect on organizational citizenship behavior. In addition to workplace behavior and job performance, organizational justice has also been linked closely with other job attitudes and behavior. A review conducted by Cohen- 
Charash and Spector [7] from 190 research showed that organizational justice plays a key role in shaping attitudes such as satisfaction and commitment, as well as extra role behavior and counterproductive behavior.

Colquitt et al. [8] conducted a meta-analysis of studies on organizational justice and find that there is a relationship between overall fairness and other important organizational results, including performance. Specifically, result of study found that procedural and distributive justice has a relatively strong correlation with attitudinal outcomes such as satisfaction, job satisfaction, commitment, and trust. Interactional justice is highly correlated with authority evaluation. This relationship among variables observed in conceptual model is more predictable when observing perception of procedural justice than either distributive or interactional justice [8]. Another studies reveals that POS is fully mediates the relationship between procedural justice and OCB done by Masterson et al. [9]; Wayne et al. [10]; other result have shown that procedural justice coud affect organizational commitment directly [9] [11]. Overall, these findings suggest that the perception of organizational justice is an important for employee to evaluate quality of exchange relations with their superiors and organization. Furthermore, these findings suggest that organizational justice seem to detemine job attitudes and behaviors that lie in quality of social exchange relationships among employees with their organization.

Most research on the relationship between organizational justice and work outcomes has been conducted in a Western context. A few studies have been conducted in a non-Western context [12] [13]. In this study, we try to determine the possible existence and the direction of any relationship between organizational justice and organizational citizenship behavior with mediating effect of perceived organizational support.

\section{Empirical Background And Hypothesis Development}

This section of paper begins by providing the relevant background on this topic and then continues with a discussion of the problem that serves as the rationale for the current study. After this, the purpose of the study is addressed and the research hypotheses are presented. The section concludes by discussing the importance of the study.

\section{Relationship of Distributive Justice on Perceived Organizational Support}

Distributive justice is extent to which benefits are allocated fairly by organization [14]. Distributive justice also refers to justice received by individuals in term of rewards from an organization such as the accuracy of payments received in time and level of benefits [15]. Distributive justice is a perception of fairness of the results by the organization in conjunction with individual and group input, and Price and Mueller [16] define concept of distributive justice as "the degree to which rewards and punishments are related to performance inputs". This means that distributive justice does not refer to quantity of rewards and also punishments which dispensed by organization, but rather to the equity of the rewards divided among the employees. Distributive justice is dominated by theory of similarity, especially in terms of how people evaluate and react for different treatments which they received from others.

When peoples receives justice in term of distribution of output for their contribution that has been given for organizations, they will compare it with others in same workload perceived whether it is fair or not. By comparing it, individual will tend to improve such extra role behavior. The higher distributive justice felt by employees also foster the higher feeling of being supported by organization which they perceived [10] [14] [17] [18]. Meanwhile, although there is another connection patterns as shown by Deconinck and Johnson [19], which considered that distributive justice does not have an important effect on perceived organizational support.

Based on theoretical and empirical previously that has been discussed before, hypothesis proposed as mention below:

H1: Distributive justice has a positive effect on perceived organizational support among Lecturer in Private Universites in Bali Denpasar.

\section{Relationship of Procedural Justice on Perceived Organizational Support}

Procedural justice is referred as the procedures that are adopted by the firm whenever it takes any decision. Study of Obsborn [21] stated the procedural justice as the way of implementing relevant criteria for decision making adopted by the firm. Research studies of Van Dijke et al [22] depicts that procedures are perceived fair when applied constantly over time and people. The effects of procedural justice may provide insight into how employees and employers would achieve mutual consideration and substantial fit in managing the process of career advancement.

Procedural justice is defined as reasonableness of decision making process that leads to results, and involves whether the decision procedure, process control and dispute settlement mechanism is fair, open, consistent,and whether fair or not employees are provided every way to participate in decision-making or not [14]. The relationship between organizational justice and perceived organizational support, as described by employees who believe they are being treated fairly by organization, woud make employees should feel more supported by their organization [22]. Perceived organizational support is an important variable to explore its 
relationship with positive results for the organization. Procedural fairness is more important for employees when the organizational results are not fun for them, nor hope of results is more prominent when the procedures are to be unjust. Therefore procedural justice is often regarded as the most important thing in encouraging employees feeling that they are supported by their organization [22]. Previous research has established a relationship between POS and these results [10] [19]. However, there are some studies that discuss interventions that directly impact on POS with the positive results generated for organization, such as procedural justice [17][18].

Given the different results from previous studies, in establishing certain hypothesis is difficult to say. However, based on results of previous studies, perceived organizational support is thought to be mediator between justice and organizational result. In particular, previous studies tend to show that distributive and procedural justices are associated with POS [19]. Based on results of previous study, which consist of theoretical and empirical result that has been discussed before, research hypothesis is proposed below:

$\mathrm{H} 2$ : Procedural justice has positive effect on perceived organizational support among Lecturer in Private Universites in Bali Denpasar.

\section{Relationship of Interactional Justice on Perceived Organizational Support}

The second type of the organizational justice is the interactional justice which was introduced by the Bies and Moag [23] with an aim to focus on the quality of fairness people receive in procedural treatment or when procedures are implemented. Cropanzano and Stein [24] argued when employees are judged unfairly and treated without respect and dignity, issues with interactional justice are created. Interactional justice in organization includes various actions to display social sensitivity, such as when supervisors treat employees with respect and dignity.

Interactional justice refers to perceptions of equity in relationships between supervisors and employees. From the perspective of private universities, as faculty member lecturer perceive about practice of interactional justice in which these could foster perceived organizational support. Rhoades and Eisenberger [22] assert that organizational justice as one of the important antecedents of perceived organizational support, and there are at least three dimensions or categories in the concept of organizational justice, one of which is interactional justice. Part of the problem arises is that prior studies rarely included all of the three forms of organizational justice and perceived organizational support together in a single study. For example, Shore and Shore [25] proposed that distributive justice and procedural fairness associated with the POS, but interactional justice is not included in this study. Other research shows empirical support for POS mediating the relationship between procedural justice and job results [26]. Given the positive effect of other dimension of organizational justice on perceived organizational support, it seems logical to suggest that interactional justice is related to perceived organizational support as well.Based on the study results and the theoretical and empirical (previous research) that has been discussed before the research hypothesis proposed are as below:

H3: Interactional justice has positive effect on perceived organizational support among Lecturer in Private Universites in Bali Denpasar.

\section{Relationship of Distributive Justice on Organizational Citizenship Behavior}

According to Organ et al [27], Distributive Fairness is the view of an employee that how his/ her outcome is compared to the outcome of another employee. Study of Burney, Henle and Widener [28] argue that distributive fairness is the perception of the employees that how fair actual outcome has been distributed. Basically, peoples behave positively to contribute to organizational development and give attention to their work when they have a positive perception of organizational justice. It is important that apart from of social exchange theory perspective, could explain the influence of organizational justice on OCB, which according to Niehoff and Moorman [29] can also be traced through perspective of social identity theory or the power relational model. According to social identity theory, willingness to behave positively will support to organizational objectives because of the identification which felt by people. It can be arised because a person perceives about allocation or distribution of rights and obligations from organization.

Although focused attention is arise on construct of justice, fundamental issues about the strength of the relationship between distributive justice to organizational results and implications of this relationship needs to be addressed. In particular, any attempt to determine strength of the relationship and extent to which changes in magnitude because of changing situation of study (ie, contextual sensitivity). It is important to investigating the extent in which relationship of distributive justice is influenced by the potential research methods and measurement constructs to address these issues.

Some findings which successfully uncovered by DeConnick and Johnson [19] showed that negative consequences occured when employees felt that they have been treated unfairly. Thus, organization needs to determine whether employees feel that they are being treated unfairly. An important point is that perception of fairness, whether accurate or inaccurate, can guide a person's behavior [19]. Organization needs to determine 
whether peoples feel that they are being rewarded fairly for their efforts (distributive justice), then it would be perceived positively in guiding their behavior in work.

Based on results of previous study, which consist of theoretical and empirical result that has been discussed before, research hypothesis proposed below:

H4: Distributive justice has positive effect on organizational citizenship behavior among Lecturer in Private Universites in Bali Denpasar.

\section{Relationship of Procedural Justice on Organizational Citizenship Behavior}

It is believed and examined that organizational citizenship behavior is largely encouraged by perceived organizational Justice. Especially when considering about organizational citizenship behavior, it is typical extrarole behavior which is convenient for employees to adjust and balance the perceived justice or injustice feeling. Procedural justice also important for individuals within the organization, such as the procedure sharing, decision-making process, performance assessment procedures, and more to encourage feeling that a person feels supported by organization. Besides the perception of procedural justice can encourage employees to behave in extra role in form of OCB well against organization. When someone receives procedural justice of the allocation decisions are felt by someone with the same perception with others, it is likely to improve extra role behavior such as OCB.

Several previous studies have revealed the relationship between perceptions of justice and organizational citizenship behavior. Asgari et al [30] have stated the possibility of organizational citizenship behavior (OCB) among individuals increased when perception of fair treatment by supervisor and organization is positive. In other words, organizational citizenship behavior would be higher when employees see fair treatment perceived by supervisors as more positively.

Based on results of previous study, which consist of theoretical and empirical result that has been discussed before, therefore it is proposed as hypotheses below:

H5: Procedural justice has positive effect on organizational citizenship behavior among Lecturer in Private Universites in Bali Denpasar.

\section{Relationship of Interactional Justice on Organizational Citizenship Behavior}

Interactional Justice which was introduced by the Bies and Moag [23] with an aim to focus on the quality of fairness people receive in procedural treatment or when procedures are implemented. Generally, what is observed in recent organizational theories focused mostly on the interpersonal interactions. Organizational problems based on these interactions arise and also determining the quality of social interaction. It is emphasized that the perception of people about the rights and fairness in the organizational life will led them into positive work behavior such as extra role behavior.

Specifically, an individual is easier to blame untimely attribute of information and explanations are inadequate to the will of the supervisors who deliberately unfair because this supervisors has more control over discretionary behavior [31]. Individual tend to throw an error in perceiving injustice of information and interaction on a supervisor because he or she is proximal one of the organization (eg, employers) in hiring individuals in whom not provide information updates and explanations. This would help employees to complete homework assignments at daily meetings. Chiaburu and Lim [32] have underlined that interactional justice able to predict OCB, with the impact is greater than procedural justice. As one of the dimensions of justice, interactional justice is seen as avalaible factor to drive extra role behavior such as OCB.

Further argues that peoples trying to avoid those relationships that are inequitable and unjust, because of individuals compare themselves with others in term of their outcomes. Peoples maintain just only equitable and fair relationship between themselves. Interactional justice is its necessity for the workers personal quality of social interaction and effective functioning of the organization.

Based on results of previous study, which consist of theoretical and empirical result that has been discussed before, research hypothesis proposed below:

H6: Interactional justice has positive effect on organizational citizenship behavior among Lecturer in Private Universites in Bali Denpasar.

\section{Relationship of Perceived Organizational Support on Organizational Citizenship Behavior}

The findings of some previous studies suggest that organizational citizenship behavior could be seen as result of a process of social exchange in which employees feel the availability of perceived organizational support and concern as a result of interpersonal treatment and fair information from organization [31]. Employees who believe their socio-emotional needs are met by the organization may have felt an obligation to reciprocate back by doing the behavior is beneficial to the organization and its members, social exchange theory describing various interpersonal transactions that occur throughout a person's social life. More specifically, the individual can shape economic exchange and the exchange relationship sosial. Organ (1997) describes the OCB 
as individual behavior discretion indirectly or explicitly recognized by the formal reward system, and in the aggregate promotes the effective functioning of the organization. Discretionary means that employee behavior is not a requirement that must be carried out of the role or the specific job description of a contract employee with the organization, but such behavior is more a matter of personal choice, so if there is negligence, there is generally no penalty. This personal selection will increase the possibility to do if someone who feels supported or considered by the organization.

Research construct POS and OCB reveal the underlying logic: the general perception of employees that organizations reward individuals linked to the overall perception of organizational support, which is expected to encourage employees to respond with an increase in the behavior of the extra roles such as OCB [10] [26] [30] [34]. Previous study noted on POS since the meta-analysis by Rhoades and Eisenberger [22] which continues to support the conclusion that there is a positive and important relationship between POS and extra-role performance. However the perceived organizational support has been widely tested in previous studies with regard to the performance of employees, turnover intention, and organizational membership behavior [10] [30] [34]. Although the results of empirical studies have reported a positive relationship between POS and organizational citizenship behavior of employees, few studies have been reveals such construct that considered as conceptually different in which its relation to organizational citizenship behavior.

Based on results of previous study, which consist of theoretical and empirical result that has been discussed before, research hypothesis proposed below:

H7: Perceived organizational support has positive effect on organizational citizenship behavior among Lecturer in Private Universites in Bali Denpasar.

\section{Mediating Role of Perceived Organizational Support on Effect of Distributive Justice, Procedural Justice and Interactional Justice against Organizational Citizenship Behavior}

Building on the results of studies linking distributive, procedural, and interactional justice with organizational citizenship behaviors, it is therefore proposed that three component of justice will indirectly exert its effects on OCBs through perceived organizational support. Moreover, it is also proposed that the relationships among distributive, procedural, and interactional justice, and citizenship behaviors may constitute an interaction relationship as well. Loi et al. [12] examined the relationship between justice perceptions, perceived organizational support, organizational commitment and intention to leave among employees in Hong Kong. The study reported that both procedural and distributive justice have significant functional effects on organizational commitment and intention to leave, mediated through perceived organizational support.

Procedural justice would refers to formal decision making process, while interactional justice refers to the interpersonal treatment received by individual in organization during the implementation of the process. Bies and Moag [23] noted that procedural justice would have effect on perceptions of trust toward the organization, whereas interpersonal justice would have effect on perceptions of trust for supervisor. Each form of justice, which consist of distributive justice, procedural justice, and interactional justice can be related to perceived organizational support [10][17][18][19]. The findings of Moorman, Blakely, Niehoff [26] study generally show the mediating role of POS, is fully able to strengthen the impact of the relationship between procedural justice on OCB. These results indicate that procedural fairness is an antecedent of POS, and POS itself have strengthening the effect toward OCB. Particular study such as Deconinck and Johnson [19] which tested 384 salespeople who responded to the study, and tested the effects of three dimensions of organizational justice to POS. Research findings reveal that procedural justice is able to predict POS significantly. Distributive justice does not have an important impact on POS. Interpersonal justice does not affect the POS directly, but through perceived supervisor support.

Another study by Gillet et al. [35] connects procedural justice, autonomy supervisor support, satisfaction of needs, POS, job satisfaction, organizational identification and job performance. Procedural justice and autonomy supervisor support have positive and significant impact on satisfaction of the needs and perceived organizational support, which in turn will have a positive impact on job satisfaction, organizational identification and job performance[36]. The research findings by Gillet et al. [35] suggested that organizations can deliver training programs for their managers, which the aims is to increase the use of fair procedures in allocating the results and develop autonomy supportive behaviors to improve job satisfaction, organizational identification and job performance. This findings reveal that there a social exchange mechanism about form of justice toward perceived organizational support.

Furthermore, perceved organizational support for researchers would be seen as important antecedent for organizational citizenship behavior [10] [30] [31] [34]. Both the nature of these relationships (Organizational justice $\rightarrow$ POS and POS $\rightarrow$ OCB) taken into empirical foundation that POS may mediate the relationship between organizational justices on organizational citizenship behavior.

Based on the study results and the theoretical and empirical (previous research) that has been discussed before the research hypotheses proposed below: 
H8: Perceived organizational support has an important mediating role in the effect of distributive justice on organizational citizenship behavior among Lecturer in Private Universites in Bali Denpasar.

H9: Perceived organizational support has an important mediating role in the effect of procedural justice on organizational citizenship behavior among Lecturer in Private Universites in Bali Denpasar.

H10: Perceived organizational support has an important mediating role in the effect of interactional justice on organizational citizenship behavior among Lecturer in Private Universites in Bali Denpasar.

\section{Objectives of The Study}

This study intends to seek a solution and the solution in addressing the problems among lecturers in private university about their perceived organizational support and organizational citizenship behavior by sticking and concentrate on organizational justice component.

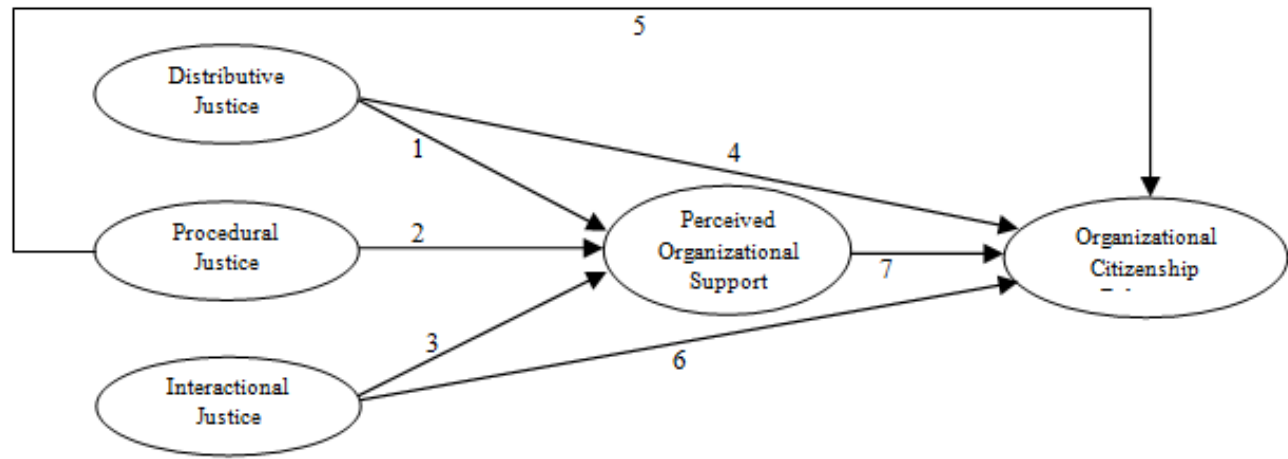

Figure 1 Conceptual Framework

Source :

1. Niehoff and Moorman (1993), Shore and Shore (1995), Wayne, et al. (2002), DeConnick and Johnson (2009), DeConnick (2010), Mukherjee (2010), Gillet et al. (2013).

2. Niehoff and Moorman (1993), Shore and Shore (1995), Moorman, Blakely, Niehoff (1998), Wayne, et al. (2002), Rhoades and Eisenberger (2002), DeConnick and Johnson (2009), DeConnick (2010), Mukherjee (2010).

3. Niehoff and Moorman (1993), DeConnick and Johnson (2009), Mukherjee (2010), Cheung (2013).

4. Moorman (1991), Moorman (2003), Organ and Ryan (1995), Guh et al (2013).

5. Moorman (1991), Moorman (2003), Organ and Ryan (1995), Guh et al (2013).

6. Moorman (1991), Moorman (2003), Organ and Ryan (1995), Chiaburu and Lim (2008), Guh et al (2013), Cheung (2013).

7. Niehoff and Moorman (1993), Moorman, Blakely, Niehoff (1998), Wayne, et al. (2002), Asgari et al (2008), Liu (2009), Cheung (2013)

\section{Sample}

\section{Methodology}

This research was conducted in scope of Private Universities among under supervision of coordination of private universities Region VIII Denpasar Bali. The unit of analysis in this research is lecturers who assigned to the Private universities in Denpasar area. Convenience sampling was used to determine number of sample, and from duration of research (one month, in May 2016) about 85 lecturers identified as respondent. All of respondents identified asked each of them to agree or decline to participate. They were given the questionnaires, assured complete of their responses of all items provided, and requested to return the filled-in questionnaires within a fortnight. The questionnaires were collected personally.

\section{Measures}

By using likert's scale ranging from zero to five $(0=$ Never, $5=$ Often $)$, the instrument was developed which combined portions of existing surveys related to distributive justice, procedural justice, interactional justice, perceived organizational support and organizational citizenship behavior among lecturers in private universities in Denpasar Bali.

Distributive Justice: Distributive justice in this study refers to the perceived fairness from organization of an individual outcomes. Perceptions of distributive justice were measured with a 5-item scale developed by Neihoff and Moorman [29]. Respondents indicated the extent of their agreement or disagreement with each item on a scale from 1 (strongly disagree) to 5 (strongly agree).

Procedural Justice: Perceptions of procedural justice in this study refers to perceptions about the fairness of the rules and procedures that regulate a process. This construct were measured with a 4-item scale developed by Neihoff and Moorman [29]. Employees responded to each item using a 5-points Likert scale. 
Interactional Justice: Perceptions of Interactional justice were measured with 4-items measuring the degree to which employees felt their needs were considered, and adequate explanations were made for job decisions. All items used a five-point format.

Perceived Organizational Support : POS refers to employees' generalized beliefs about the extent to which the organization values their contributions and cares about their well-being (Eisenberger et al, 1986).. POS was measured using Eisenberger et al.'s [37] Survey of Perceived Organizational Support. Respondents rate their agreement for each of the 6-items using a 5-point Likert scale.

Organizational Citizenship Behavior : OCB is the tool through which the organization can efficiently perform its operation [27]. Respondents rate their agreement for each of the 5-items of OCB using a 5-point Likert scale.

\section{Data Analysis}

The data reliability tested before analysis with using parameter of Cronbach's alpha (if the alpha value is over 0.6, it is appropriate to present consistency). In this research, the Cronbach's alpha value of distributive justice is 0.825 , procedural justice is 0.762 , interactional justice is 0.776 , perceived organizational support is 0.861 , organizational citizenship behavior is 0.686 . The hypotheses are tested by cross-sectional data with the use of SPSS 23.0 and SmartPLS Version 2.0.M3 to test the research hypotheses based on structural equation modeling using partial least squares (PLS) approach. PLS is a next generation of multivariate technique [38] which can simultaneously evaluate the measurement model, and the structural model with the aim to minimize error variance. The method which used to supports the theoretical development of standard path models for assessing the success drivers of certain target constructs with key relevance.

\section{Result And Discussion}

TABLE 1 below summarizes the demographic characteristics of the respondents. From the demographic profiles of the respondents reveals that 51 were male, while 34 were female lecturers. The table shows that the survey respondents were predominantly male (60 percent male versus 40 percent female). Otherwise, $8(9,40 \%)$ were $28-37$ years old, $17(20 \%)$ were $38-47$ years old, while $60(70,60 \%)$ were exceeded 47 years old. Subjects' age ranged exceed 47 years old the most respondent who participated in this study. Respondents whom their age ranged from 28 - 37 years old are the small number sample, which just eight people. Regarding their highest education background, 1 people or 1,20 percent only have bachelor degree, 64 respondents or 75,30 percent obtained master degree, 20 respondent or 23,50 percent obtained doctoral degree. In terms of years of work tenure, out of 85 respondents, $3.60 \%$ of them, their years of experience ranged from 1 and 5, 17,60\% ranged from 6 and 11 year, 10.60\% ranged from 12 and 17 year, and last $68.20 \%$ exceeded 17 years. It could be argued that respondent in this study were mature enough in experiencing their lecturing profession.

Descriptive statistic Highest mean score of variable that is interactional justice of Lecturer in Kopertis Region VIII Denpasar, particularly on respect in general perceived by lecturer Kopertis Region VIII Bali Denpasar, more prominent than other concepts. Interactional justice practice basically has been perceived both by lecturers Kopertis Region VIII Bali Denpasar. But in general the average score for the variable observed in this study was high (range from 4.11 OCB construct as the lowest avarege score to 4.265 as highest average score of interactional justice).

Table 1 Demographic profile of respondents

\begin{tabular}{|l|l|c|r|}
\hline Demographics & Categories & Frequency & \% \\
\hline \multirow{4}{*}{ Gender } & Male & 51 & 60,00 \\
\cline { 2 - 4 } & Female & 34 & 40,00 \\
\hline \multirow{4}{*}{ Level of Education } & $28-37$ & 8 & 9,40 \\
\cline { 2 - 4 } & $38-47$ & 17 & 20,00 \\
\cline { 2 - 4 } & $>47$ & 60 & 70,60 \\
\cline { 2 - 4 } & Bachelor Degree & 1 & 1,20 \\
\cline { 2 - 4 } & Master Degree & 64 & 75,30 \\
\cline { 2 - 4 } & Doctoral Degree & 20 & 23,50 \\
\hline \multirow{5}{*}{ Work Tenure } & $1-5$ year & 3 & 3,60 \\
\cline { 2 - 4 } & $6-11$ year & 15 & 17,60 \\
\cline { 2 - 4 } & $12-17$ year & 9 & 68,20 \\
\cline { 2 - 4 } & $>17$ year & 58 & \\
\hline
\end{tabular}

As depicted in TABLE 2, outer loadings, Average Variance Extracted (AVE) and composite reliability can be assessed to confirm discriminant and convergent validity among constructs in study. We assess the discriminant validity by using the average variance extracted (Fornell and Lacker, 1981). It captures average variance shared between a construct and its measures. This measure should be greater than variance shared 
between the construct and other constructs in the model. Convergent validity indicates degree to which theoretically similar constructs are highly correlated with each other whereas discriminant validity indicates degree to which a given construct is different from other constructs.

AVE is the mean variance extracted for the items loading on a construct and is a summary indicator of convergence [39]. An AVE value of at least 0.5 indicates sufficient convergent validity. The average variance extracted (AVE) of the constructs as shown in TABLE 2 found above 0,5; which this means a good convergent validity gained in this study supports about good reflective measurement models. Meanwhile composite reliability (CR) is assessed for reliability, which is a another measure of convergent validity. The composite reliability value should be higher than 0.7 to assure an accurate scale. So it can be argued that the measures used provide a satisfactory level of reliability.

Table 2 AVE Construct, Outer Loadings and Mean

\begin{tabular}{|c|c|c|c|c|c|}
\hline Construct & $\mathbf{A V E}^{\mathbf{a}}$ & $\mathbf{C R}^{\mathbf{b}}$ & Item & $\begin{array}{c}\text { Outer } \\
\text { Loading }\end{array}$ & Mean \\
\hline \multirow{5}{*}{$\begin{array}{l}\text { Distributive } \\
\text { Justice }\end{array}$} & \multirow{5}{*}{0,590} & \multirow{5}{*}{0,878} & Level of pay is fair & 0,737 & 4,16 \\
\hline & & & Overall the rewards quite fair & 0,806 & 4,18 \\
\hline & & & Work schedule is fair & 0,805 & 4,16 \\
\hline & & & Work load to be quite fair & 0,732 & 4,29 \\
\hline & & & Feeling about job responsibilities & 0,756 & 4,16 \\
\hline \multirow{4}{*}{$\begin{array}{l}\text { Procedural } \\
\text { Justice }\end{array}$} & \multirow{4}{*}{0,588} & \multirow{4}{*}{0,851} & Fairness in formal procedure & 0,728 & 4,25 \\
\hline & & & Treats with kindness and consideration & 0,772 & 4,32 \\
\hline & & & Treats with respect and dignity & 0,771 & 4,18 \\
\hline & & & Adequately explains decisions & 0,794 & 4,26 \\
\hline \multirow{4}{*}{$\begin{array}{c}\text { Interactional } \\
\text { Justice }\end{array}$} & \multirow{4}{*}{0,598} & \multirow{4}{*}{0,855} & Respect & 0,697 & 4,38 \\
\hline & & & Propriety & 0,843 & 4,31 \\
\hline & & & Justification & 0,747 & 4,15 \\
\hline & & & Truthfulness & 0,798 & 4,22 \\
\hline \multirow{6}{*}{$\begin{array}{c}\text { Perceived } \\
\text { Organizational } \\
\text { Support }\end{array}$} & \multirow{6}{*}{0,603} & \multirow{6}{*}{0,899} & The organization cares about my opinions & 0,810 & 4,27 \\
\hline & & & Organization takes pride in accomplishments & 0,665 & 4,35 \\
\hline & & & Organization values my contribution & 0,859 & 4,02 \\
\hline & & & Organization appreciate any extra effort & 0,861 & 4,07 \\
\hline & & & Organization care about problem & 0,843 & 3,94 \\
\hline & & & Organization really cares about my well-being & 0,575 & 3,98 \\
\hline \multirow{5}{*}{$\begin{array}{l}\text { Organizational } \\
\text { Citizenship } \\
\text { Behavior }\end{array}$} & \multirow{5}{*}{0,503} & \multirow{5}{*}{0,793} & Conscientiousness & 0,522 & 4,00 \\
\hline & & & Altruism & 0,501 & 3,87 \\
\hline & & & Civic Virtue & 0,674 & 4,18 \\
\hline & & & Sportmanship & 0,826 & 4,19 \\
\hline & & & Courtesy & 0,753 & 4,31 \\
\hline
\end{tabular}

Note.

a Average variance extracted (AVE) $=$ (summation of the square of the factor loadings)/\{(summation of the square of the factor loadings) / (summation of the error variances)

b Composite reliability $(\mathrm{CR})=$ (square of the summation of the factor loadings)/ (square of the summation of the factor loadings) / (square of the summation of the error variances)

Loading factor of manifest variables were observed in this study provides fact that organization appreciate any extra effort for lecturers is an indicator with the largest weighting factor that reflects perceived organizational support felt by lecturers. This loading factor value is also the biggest loading factor weight values of the indicators observed in this study to reflect the latent variables. The findings of this study support the concept of perceived organizational support as highly reliable construct with highest Cronbach's alpha and composite reliability compared to other research constructs. Feeling supported by organization accepted as a form of reflection of how the organizational management looked at a person's contribution to the institutions in which they work. From the test results of outer models measurements in this study, all of the constructs were observed to have met criteria for discriminant validity and composite reliability. Organizational citizenship behavior found to have a lowest value of composite reliability when it is compared to the other constructs observed in this study. Additionally for entire construct which is convergent validity observed in this study met the criteria.

Result indicates that distributive justice primary reflected by fairness of overall the rewards received by lecturers in private universities. Procedural justice was mainly reflected by adequately explains decisions, and interactional justice was mostly reflected by propriety. Perceived organizational support was mainly reflected by organization which appreciate any extra effort from lecturers; thus, organizational citizenship behavior principally manifested by sportmanship of behavior shown by lecturers. 
Table 3 Beta Coefficients

\begin{tabular}{|l|l|l|l|}
\hline Relationship Among Variables & $\begin{array}{l}\text { Original } \\
\text { Sample } \\
\text { Estimate }\end{array}$ & t-statistic & Note \\
\hline Distributive Justice -> Perceived Organizational Support & 0,333 & 4,3539 & Sign. \\
\hline Procedural Justice -> Perceived Organizational Support & 0,148 & 2,2942 & Sign. \\
\hline Interactional Justice -> Perceived Organizational Support & 0,466 & 7,7065 & Sign. \\
\hline Distributive Justice -> Organizational Citizenship Behavior & 0,149 & 1,1664 & NS \\
\hline Procedural Justice -> Organizational Citizenship Behavior & 0,210 & 1,5822 & NS \\
\hline Interactional Justice -> Organizational Citizenship Behavior & 0,288 & 2,4209 & Sign. \\
\hline Perceived Organizational Support -> Organizational Citizenship Behavior & 0,312 & 2,0796 & Sign. \\
\hline
\end{tabular}

The structural model indicates the causal relationships among constructs in the model. It includes estimates of the path coefficients, which indicate the strengths of the hypothesized relationship (i.e. the relationship between the dependent and independent variables), and the $\mathrm{R}_{\text {square }}$ value, which determine the predicting power of the model (i.e. the amount of variance explained by the independent variables). Together, the $\mathrm{R}_{\text {square }}$ and the path coefficients (loadings and significance) indicate how well the data support and hypothesized model [40].

TABLE 3 show result of data analyis which reveals the significance of all relationship observed in this study. There are two relationships among variables are not significant, the effect of distributive justice and procedural justice on organizational citizenship behavior. This means as the level of distributive and procedural justice increase so it will not have an important impact on the level of organizational citizenship behavior. From findings above, we are also shown that the greatest impact of all effect was interactional justice on perceived organizational support.

Figure 2 shows the results of the test of the hypothesized structural model from data analysis. As expected, distributive justice (0.333), procedural justice $(0.148)$, and interactional justice $(0.466)$ had significant influences on perceived organizational support and accounted for 72.29 percent of the variance in POS. In addition, distributive justice $(0.333)$ and procedural justice $(0.148)$ had no significant effect on organizational citizenship behavior. While interactional justice $(0,288)$ and perceived organizational support $(0,312)$ had significant influence on organizational citizenship behavior, accounting for 35.80 percent of its variance.

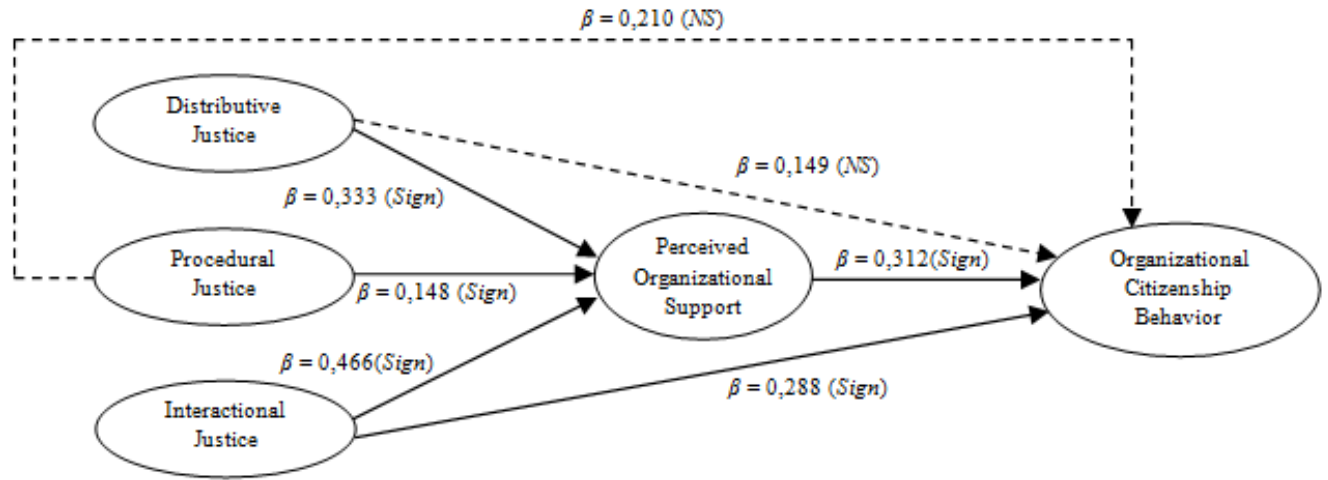

Figure 2 Path Coefficent between Variables

Result of each hypothesis which is tested in this study shown in TABLE 4 below.

Table 4 Result of Hypotheses

\begin{tabular}{|l|l|l|}
\hline Relationship & $\begin{array}{l}\text { Hypothesis } \\
\text { Testing Result }\end{array}$ & Remark \\
\hline DJ $\rightarrow$ POS & H1 Accepted & \\
\hline PJ $\rightarrow$ POS & H2 Accepted & \\
\hline IJ $\rightarrow$ POS & H3 Accepted & Highest beta coefficient \\
\hline DJ $\rightarrow$ OCB & H4 Rejected & Beta coefficient was not significant \\
\hline PJ $\rightarrow$ OCB & H5 Rejected & Beta coefficient was not significant \\
\hline IJ $\rightarrow$ OCB & H6 Accepted & \\
\hline POS $\rightarrow$ OCB & H7 Accepted & \\
\hline DJ $\rightarrow$ POS $\rightarrow$ OCB & H8 Accepted & \\
\hline PJ $\rightarrow$ POS $\rightarrow$ OCB & H9 Accepted & \\
\hline IJ $\rightarrow$ POS $\rightarrow$ OCB & H10 Accepted & \\
\hline
\end{tabular}

Note : DJ = Distributive Justice; PJ = Procedural Justice; IJ = Interactional Justice; POS = Perceived Organizational Support; OCB : Organizational Citizenship Behavior. 


\section{Conclusion}

While prior research on distributive justice, procedural justice, interactional justice has contributed to a deeper understanding of these constructs and of their relationships with perceived organizational support and organizational citizenship behavior, few empirical studies have comprehensively examined, from an individual perspective. Besides of that, there are the mediating role of perceived organizational support on the relationships between distributive, procedural, and interactional justice and organizational citizenship behavior. The results of analysis have reveals two of all the hypotheses proposed are not accepted in this study with reference to significance of coefficient of influence of the relationship between variables. The first is the direct influence of distributive justice on organizational citizenship behavior; the second is procedural justice directly against organizational citizenship behavior.

The relationship between variables were observed in this study, the greatest impact was found in interactional justice influencing perceived organizational support. The coefficient of influence on that relationship was found the largest compared to the coefficient of influence on other links within this research model. The findings of the research also draw conclusions that there is a mediating effect of perceived organizational support on the influence of distributive justice, procedural justice, and interactional justice on the behavior of organizational membership. Effects of organizational justice dimension of the work behaviors are reinforced by the perception of perceived organizational support. Distributive justice and procedural fairness can not have significant influence on the behavior of organizational membership. To foster organizational citizenship behavior, Lecturer of private universities in Denpasar Bali who have felt fairness within the institution must feel that they are supported and cared nu institution.

Research findings reveal the importance of interactional justice in driving extra role behavior directly, or amplified on its effects through a sense supported by institution where the lecturers are working in. Emphasis on interactional justice is due to focus on the development of respect as a reflection of justice felt by lecturer, thus encouraging feeling supported by private universities where they teach, to then be able to stimulate organizational citizenship behavior.The image shows the final conceptual framework model compiled after take off track relationships between variables are not significant. Model final conceptual framework was prepared by eliminating lines no significant relationship between the others, there are two direct relationships which is not significant were distributive justice and procedural fairness on organizational citizenship behavior. In the context of this study, results and findings have uncovered that perceived organizational support can play an important role in strengthening the effects of distributive justice, procedural justice, and interactional justice on organizational citizenship behavior.

Our results clearly reveal that only interactional justice play directly or indirectly, as a determining role in the development of organizational citizenship behavior. Cultivating a sense of interactional justice may benefit an organization through increased perceived organizational support and Organizational citizenship behavior. According to treat lecturers, private universities leader are suggested treating them with respect and dignity, and are sensitive to their personal needs. Leader of private universities in Denpasar Bali advised to deal with lecturers in a truthful manner, and when making decisions concerning their job, they discuss the implications with them. This would foster the feeling of being supported by organization, which it will cause greater extra role behavior among lecturers in private universities in Denpasar Bali.

However, there are still some limitations about the research. First, the data is collected through selfreporting questionnaire. For example, organizational justice, perceived organizational support, and organizational citizenship behavior are measured according to respondents' own attitudes. In the future research, it could be improved by asking respondent's superior and colleague to answer relative questionnaires and measuring required items more accurately. Thus, measurement of organizational justice, focus in measuring the three dimensions of organizational justice, in this current study used survey items that asked employees to respond to items that asked whether something is generally fair. When focusing on organizational justice which consist of distributive, procedural, and interactional justice, it has been assumed that employees consider fairness to themselves.

For lecturers in private universities of Kopertis Region VIII Denpasar, to keep a positive attitude can encourage the creation of a sense of justice in the organization that is more focused and good atmosphere given the importance in the organizational justice in order to encourage a positive attitude and behavior shown in work activities. For private universities of Kopertis Region VIII Denpasar Bali, there is a need to continue supporting and pay attention for lecturer in the institution. This is based on research findings that show importance of Lecturer's feeling supported by institutions where they are placed.

For further research, it is advisable to consider the organization as a multidimensional concept of justice, or simply a construct of organizational justice. Considering that the impact of each dimension of organizational justice may be differs to influence attitudes and behavior of individuals. The findings also raise issues about the possible effects of constructs not included in this study. Employee behavior may be viewed as mixed-level, incorporating individual, group, and organizational level phenomena. It is advisable to consider the 
other factors than organizational justice and perceived organizational support which can give the effect on organizational citizenship behavior. Integration of these factors in the organizational justice model for extra role behavior expected giving more comprehensive understanding of how extra role of individual behavior can be increased.

Future research can provide additional information and extensions to these propositions. For example, more information is needed on the mechanisms through which organizational justice and perceived organizational support translates into increased organizational citizenship behavior. We focused mainly on the organizational support as the main predictor of organizational citizenship behavior. It would be interesting, for instance, to identify the predictors of organizational citizenship behavior for other professional groups in other sector wheter it is public, private and consulting firms.

\section{Acknowledgements}

The authors would like to thanks for every lecturers in private universities in Denpasar Bali who participated in this study.

\section{References}

[1]. Podsakoff, P. M., MacKenzie, S. B., Paine, J. B., \& Bachrach, D. G., Organizational citizenship behaviors: A critical review of the theoretical and empirical literature and suggestions for future research, Journal of Management, 26, 2000, 513-563.

[2]. Wayne; Sandy J, Lynn M Shore;,Robert C Liden, Perceived Organizational Support and Leader-Member Exchange : A Social Exchange Perspective, Academy of Management Journal; Vol 40 No 1, 1997, 82 - 111.

[3]. Eisenberger, R., Armeli, S., Rexwinkel, B., Lynch, P. D., Rhoades, L., Reciprocation of perceived organizational support, Journal of Applied Psychology, 86(1), 2001, 42-51.

[4]. Shore, L. M., Wayne, S. J., Commitment and employee behavior: Comparison of affective commitment and continuance commitment with perceived organizational support, Journal of Applied Psychology, 78, 1993, 774-780.

[5]. Greenberg, Jerald, Organizational justice: Yesterday, today, and tomorrow, Journal of Management, 16 (2), 1990, 399-432

[6]. Konosvky, M.A. Pugh, S.D, Citizenship behavior and social exchange, Academy of Management Journal, Vol. 37 No. 3, 1994, pp. 656-669.

[7]. Cohen-Charash, Y., Spector, P.E., The role of justice in organizations: a meta-analysis, Organizational Behavior and Human Decision Processes, Vol. 86 No. 2, 2001, pp. 278-321.

[8]. Colquitt, J.A., Conlon, D.E., Wesson, J., Porter, O.L.H. and Ng, K.Y.,Justice at the millennium: a meta-analytic review of 25 years of organizational justice research, Journal of Applied Psychology, Vol. 86 No. 3, 2001, pp. 425-445.

[9]. Masterson, S.S., Lewis, K., Goldman, B.M. and Taylor, M.S., Integrating justice and social exchange: the differing effects of procedures and treatment on work relationships, Academy of Management Journal, Vol. 43 No. 4, 2000, pp. $738-748$.

[10]. Wayne, S.J., Shore, L.M., Bommer, W.H., Tetrick, L.E., The role of fair treatment and rewards in perceptions of organizational support and leader-member exchange, Journal of Applied Psychology, 87 (3), 2002, 590-598

[11]. Byrne, Zinta S, How Do Procedural And Interactional Justice Influence Multiple Levels of Organizational Outcomes?.Presentation for the fourteenth annual conference of the Society for Industrial and Organizational Psychology in Atlanta, GA, April 30 - May 2 , 1999.

[12]. Loi, R., Hang-Yue, N. and Foley, S., Linking employees' justice perceptions to organizational commitment and intention to leave: the mediating role of perceived organizational support, Journal of Occupational and Organizational Psychology, Vol. 79, 2006, pp. 101-20.

[13]. Suliman, A.M.T., Links between justice, satisfaction and performance in the workplace: a survey in the UAE and Arabic context, Journal of Management Development, Vol. 26 No. 4, 2007, pp. 294-311.

[14]. Niehoff. Brian. P., \& Moorman. Robert. H, Justice As a Mediator Of The Relationship Between Methods Of Monitoring and Organizational Citizenship Behavior, Academy of Managemet Journal. Vol.36. No.3. 1993, 527-556.

[15]. Hauenstein, Neil M. A., Tim McGonigle, Sharon W. Flinder, A Meta-Analysis of the Relationship Between Procedural Justice and Distributive Justice: Implications for Justice Research, Employee Responsibilities and Rights Journal, Vol. 13, No. 1, March 2001.

[16]. Price, J. L., \& Mueller, C. W., Distributive justice, In J. L. Price \& C. W. Muller (Eds.), Handbook of organizational measurement 1986, 122-127, MA: Pitman.

[17]. DeConinck, James B., The effect of organizational justice, perceived organizational support, and perceived supervisor support on marketing employees' level of trust. Journal of Business Research 63, 2010, 1349-1355.

[18]. Mukherjee, Kamal. Exploring the Mediating Effect of Perceived Organizational Support Between Organizational Justice Dimensions and Affective Commitment. GMJ Vol 4, Issue $1 \& 2$, 2010, January - Desember 2010.

[19]. DeConinck, James B.,Julie T. Johnson, The Effects of Perceived Supervisor Support, Perceived Organizational Support, and Organizational Justice on Turnover Among Salespeople. Journal of Personal Selling \& Sales Management, vol. XXIX, no. 4 (fall 2009), pp. 333-350

[20]. Obsborn, J.S., Components of empowerment and how they differentially relate to empowerment and satisfaction, organizational commitment and intent to leave the job. Dissertation, Vanderbilt University, 2002, [Online] Available: www.proquest.com (June 19, 2014).

[21]. Van Dijke, M., De Cremer, D., Mayer, D. M., \& Van Quaquebeke, N., When does procedural fairness promote organizational citizenship behavior? Integrating empowering leadership types in relational justice models. Organizational Behavior and Human Decision Processes, 117(2), 2012, 235-248.

[22]. Rhoades, Linda, Robert Eisenberger, Perceived Organizational Support: A Review of the Literature, American Psychological Association, Inc. : Journal of Applied Psychology Vol 87, No. 4, 2002, 698 - 714.

[23]. Bies, R.J and Moag, J.S., International Justice: communication criteria of fairness. Research on Negotiation in Organizations. (Vol. 1), 1986, Greenwich, CT: JAI Press, 43-55

[24]. Cropanzano, R., Stein, J. H., Organizational Justice \& Behavioral Ethics:Promises \&Prospects, Business Ethics Quarterly, 19, 2009, 193-233. 
[25]. Shore, L. M., \& Shore, T. H., Perceived organizational support and organizational justice, In R. S. Cropanzano \& K. M. Kacmar (Eds.), Organizational politics, justice, and support: Managing the social climate of the workplace (pp. 149-164).,1995, Westport, CT: Quorum.

[26]. Moorman, R. H., Blakely, G. L., Niehoff, B. P., Does perceived organizational support mediate the relationship between procedural justice and organizational citizenship behavior? Academy of Management Journal, 41(3), 1998, 351-357.

[27]. Organ, D. W., Podsakoff, P. M., and MacKenzie, S. B., Organizational citizenship behavior: Its nature, antecedents, and consequences, 2006, London: Sage.

[28]. Burney, L. L., Henle, C. A., Widener, S. K., A path model examining the relations among strategic performance measurement system characteristics, organizational justice, and extra-and in-role performance, Accounting, Organizations and Society, 34(3), 2006, 305-321.

[29]. Niehoff, B. F \& Moorman, R. H., Justice as a mediator of the relationship between methods of monitoring and organizational citizenship behavior, Academy of Management Journal, 36, 1993,527-556.

[30]. Asgari, Ali, Abu Daud Silong, Aminah Ahmad, Bahaman Abu Samah, The Relationship between Transformational Leadership Behaviors, Organizational Justice, Leader-Member Exchange, Perceived Organizational Support, Trust in Management and Organizational Citizenship Behaviors, European Journal of Scientific Research Vol.23 No.2, pp.227-242.

[31]. Cheung, Millissa F.Y., The mediating role of perceived organizational support in the effects of interpersonal and informational justice on organizational citizenship behaviors, Leadership dan Organization Development Journal, Vol. 34 Iss 6, 2013 , pp. $551-572$.

[32]. Chiaburu, Dan S.; Audrey S. Lim, Manager Trustworthiness or Interactional Justice? Predicting Organizational Citizenship Behaviors. Journal of Business Ethics, 83, 2008, 453-467.

[33]. Organ, D. W., Organizational citizenship behavior: Its construct clean up time. Human Performance, 10, $1997,85-97$.

[34]. Liu, Yuwen, Perceived organizational support and expatriate organizational citizenship behavior, Personnel Review, Vol. 38 Iss 3 , 2009 , pp. $307-319$.

[35]. Gillet, Nicolas, Philippe Colombat, Estelle Michinov, Anne-Marie Pronos, Evelyne Fouquereau, Procedural justice, supervisor autonomy support, work satisfaction, organizational identification and job performance: the mediating role of need satisfaction and perceived organizational support, Journal of Advanced Nursing 69(11), 2013, 2560-2571.

[36]. Guh, Wei-Yuan; Shang-Ping Lin, Chwei-Jen Fan; Chin-Fang Yang, Effects of Organizational Justice on Organizational Citizenship Behaviors Mediating Effects of Institutional Trust and Affective Commitment, Psychological Reports: Human Resources \& Marketing 112, 3, 2013, 818-834.

[37]. Eisenberger, R., Huntington, R., Hutchison, S., Sowa, D., Perceived Organizational Support. Journal of Applied Psychology, Vol 71, No 3, 1986, 500-507.

[38]. Fornell, C. and Cha, J., Partial least squares, in Bagozzi, R.P. (Ed.), Advanced Methods of Marketing Research, Blackwell Publishers, Cambridge, MA, pp. 52-78, 1994.

[39]. Fornell, C. and Lacker, D.F., Evaluation structural equation models with unobserved variables and measurement error, Journal of Marketing Research, Vol. 18 No. 1, 1981, pp. 39-50.

[40]. Chin, W.W., The partial least squares approach to structural equation modeling, in Marcoulides, G.A. (Ed.), Modern Methods for Business Research, Lawrence Erlbaum Associates, Mahwah, NJ, pp. 295-336,1998. 